\section{Teaching mechanisms}

\section{Joseph G. Gall}

\section{Molecular Biology of the Cell.}

By Bruce Alberts et al.

Garland: 1983. Pp. 1,146. Hbk \$33.95; pbk $£ 12.50$.

THE nineteenth-century promise that the study of cells, their components and their products would illuminate all aspects of biology has been amply fulfilled in recent years, so much so that writing a comprehensive treatise on cell biology is a formidable task, some would say impossible. body of biochemical information on cytoplasmic organelles or to concentrate on the molecular biology of the gene. But how is one to summarize all of that information and then show how it relates to development, neurobiology, immunology and a half-dozen other major fields?

The authors of Molecular Biology of the Cell have done it as a committee of six Bruce Alberts, Dennis Bray, Julian Lewis, Martin Raff, Keith Roberts and James Watson. What they have given us is 1,146 pretation covering virtually all those aspects of biology currently amenable to molecular and cellular analysis. And they have done it remarkably well.

Nineteen chapters are divided into three major headings: "An Introduction to the Cell" (four chapters), "The Molecular Organization of Cells"' (nine chapters) and a final section entitled "From Cells to Multicellular Organisms" (six chapters). Each chapter is divided into a small number of major headings, which in turn are discussed under subheadings. The subheadings consist of simple statements or questions in the style so popular in recent It is difficult enough to bring together the pages of detailed information and inter-

years for the titles of journal articles (e.g. "The DNA replication fork is asymmetrical", "Carbohydrate structures are modified in the Golgi apparatus", "The genetic control of development is best studied in Drosophila"'). Each subheading is then discussed in several paragraphs, with numerous references to recent, original literature and with diagrams and photographs. The illustrations have been carefully selected for their pictorial and aesthetic quality as well as for content. Nearly every major point in the text is accompanied by a diagram or photograph on the same page, enabling the reader to move effortlessly from text to picture and back.

The format of numerous small sections is well suited for simple statements of fact or for well-established generalizations, and as a didactic mechanism it focuses attention on a single issue at a time. It is somewhat less appropriate for major questions or where an important issue is still in dispute. Judiciously used, this format leaves the overall impression that problems are resolvable, at least in principle. The sense that molecular biology has clarified old issues and will continue to do so is a major theme of the work.

The amount of general information brought together here is impressive. Much of what is traditionally found in textbooks of histology and developmental biology is mentioned, and there are long chapters on the immune system, the nervous system and the special features of plant cells. Such an ambitious undertaking could easily have gone wrong. It could have given us an encyclopaedia useful for reference but not for general reading, or a disjointed compendium of good, bad and indifferent chapters. Someone has seen to it that neither of these fates befell this work. There is remarkably little duplication, the style is uniform throughout and the relative weight given to different sections has been
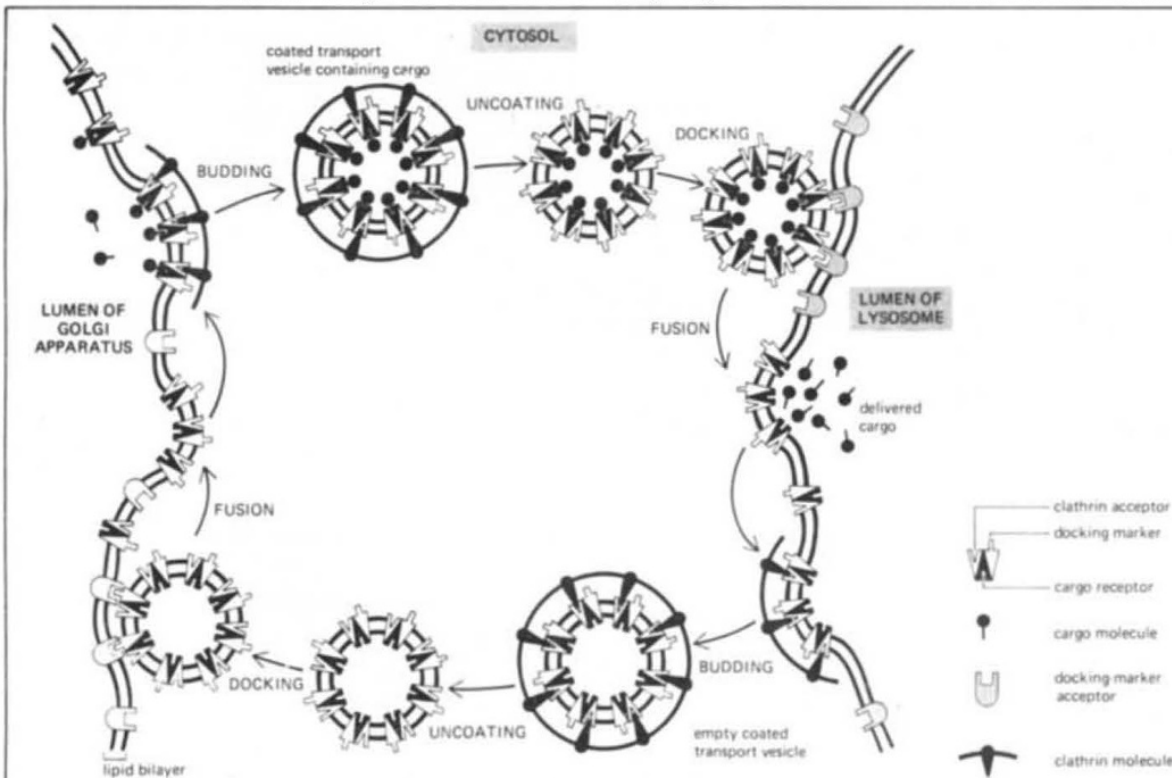

Graphic design in pedagogy, from Molecular Biology of the Cell - a highly schematic diagram of a possible mechanism allowing the targeting of coated transport vesicles to a specific intracellular membrane. The original illustration is in Iwo colours. thought out carefully. The authors and editors have also done a good job in eliminating minor errors. Much credit must go to the extensive reviews and contributions of some 75 additional people listed in the acknowledgements. In the end, however, this book is a tribute to the ability and effort of the six main authors.

For whom is the book intended? The authors say it is principally for students taking a first course in cell biology, be they undergraduates, graduate students or medical students. Certainly the level of treatment is suitable for these groups, but the amount of material would be overwhelming for a typical first course. As a practising cell biologist I found much that was new to me except in those few areas I deal with regularly. My suggestion is that this text would be ideally suited for a yearlong, middle-level course in which the traditional units in cell biology, developmental biology and molecular genetics are restructured into a single integrated presentation. There is much duplication of effort in these courses as currently taught and this text will serve a useful function if it spurs efforts at consolidation.

Molecular Biology of the Cell shows what can be done when six experts pool their talents under strong editorial leadership - an integrated, authoritative account presented in a thoroughly readable format and full of informative and attractive figures. It will be a long time before you find a better buy.

Joseph G. Gall is Ross G. Harrison Professor of Biology and Molecular Biophysics and Biochemistry at Yale University.

\section{Wanted: a new view of mountains}

\section{Janet V. Watson}

Orogeny.

By Akiho Miyashiro, Keiiti Aki and

A.M. Cclâl Şengör.

Wiley: 1982. Pp.242. Hbk £19, \$35.95; pbk $18.40, \$ 17.95$.

LIKE other sciences that established themselves in the eighteenth and early nineteenth centuries, geology has its roots in the intellectual life of Europe. Unlike other sciences, its development was determined to some extent by the structure of the European continent itself. It is fascinating to speculate on how the subject would have evolved if the founding fathers had gained their knowledge mainly from observations in Africa or Australia.

The unspoken assumption that Europe is the norm has had a particular influence on the development of ideas about orogeny, since it gave undue prominence to the atypical Alpine orogenic belt. This review of "theories of orogeny" by two 